Rose, A. H. \& Martin, S. M. (1959). J. gen. Microbiol. 20, 451-461

\title{
Studies on a Toxin-Inactivating Substance Excreted by Penicillium cyaneo-fulvum
}

\author{
By A. H. ROSE* AND S. M. MARTIN \\ Division of Applied Biology, National Research Council, \\ Ottawa, Canada
}

\begin{abstract}
SUMMARY: The reaction between staphylococcal $\alpha$-toxin and a toxin-inactivating substance (TIS) excreted by Penicillium cyaneo-fulvum was found to proceed optimally at about $\mathrm{pH} \mathbf{7 \cdot 8}$, and in the temperature range $36-44^{\circ}$. A modified assay method, based on these findings, was used to follow TIS excretion by the mould. Appearance of the active principle in the culture filtrate followed closely upon the period of active sugar utilization by the mould. TIS was excreted in quiescent cultures, but not in shake cultures. The presence of certain nutritional factors found in beef heart infusion appeared to be necessary for TIS excretion, since detoxifying activity could not be detected in filtrates from cultures of the mould grown in the absence of this nitrogen source. The marked correlation between detoxifying and protease activities of culture filtrates during growth of the mould under various conditions, as well as during purification of TIS, and its inactivation by heat and by DFP, suggested that both activities were manifestations of the same enzymic reaction.
\end{abstract}

The ability of certain moulds and bacteria to produce substances capable of inactivating bacterial toxins was first noted by Metchnikoff (1897). Other toxin-inactivating substances of microbial origin have since been reported (Ramon \& Richou, 1945; Cavalli, 1947; Smolens, McAleer \& McLaren, 1947; Del Vecchio, Del Vecchio, Napoli \& Argenziano, 1948; Villa, 1950; Richou \& Gerbeaux, 1952; Liu, 1954), although none has been characterized, nor have their modes of action been elucidated. Recently, Murray, Denton \& Stevenson (1957) showed that filtrates from cultures of a strain of Penicillium cyaneofulvum were capable of detoxifying staphylococcal $\alpha$ - and $\beta$-haemolysins, streptolysins $\mathrm{O}$ and $\mathrm{S}$, the toxins of Corynebacterium diphtheriae and Haemophilus pertussis, and clostridial toxins. These workers also reported that toxins which had been inactivated by this mould product retained their antigenic properties.

The results from a study of the reaction between staphylococcal $\alpha$-toxin and the toxin-inactivating substance (TIS) excreted by Penicillium cyaneo-fulvum have been reported briefly by Rose \& Martin (1958). The present paper gives a more detailed account of these studies, and of the development of an improved method for assaying TIS. Data are also presented which suggest that the detoxifying action of this mould product is due entirely to its proteolytic activity.

* Present address: Department of Brewing and Applied Biochemistry, Heriot-Watt College, Edinburgh. 


\section{METHODS}

Organism. The strain of Penicillium cyaneo-fulvum used in this study was obtained from Dr B. B. Diena, the culture having been isolated originally by Denton (Murray et al. 1957). Stock cultures were stored in soil (Greene \& Fred, 1934), while cultures used in routine studies were maintained on slopes of Sabouraud maltose agar ('Difco'). Spore suspensions for inoculation were obtained by flooding slope cultures with sterile water and scraping the mould surface with a sterile wire. Liquid media were inoculated with $1 \%(\mathrm{v} / \mathrm{v})$ of spore suspension (turbidity reading 75-85 at $650 \mathrm{~m} \mu$ measured with a Coleman Junior spectrophotometer). Both quiescent cultures and shake cultures (agitated at $200 \mathrm{rev} . / \mathrm{min}$. on a rotary shaker) were incubated at $28^{\circ}$.

Media. When growing Penicillium cyaneo-fulvum for the preparation of partially purified TIS, $500 \mathrm{ml}$. portions of glucose-beef heart infusion-peptone medium (Murray et al. 1957) were employed.

Excretion of TIS by the mould was studied in a basal medium (Table 1) containing one of the following nitrogen sources:

(a) Bacto beef heart infusion ('Difco'), $5 \%(w / v)$ and/or proteose peptone ('Difco') $1 \%$ (w/v).

(b) Vitamin-free casein acid hydrolysate (Wyeth Corporation), $2.5 \%(\mathrm{w} / \mathrm{v}$ ).

(c) $\left(\mathrm{NH}_{4}\right)_{2} \mathrm{SO}_{4}, 0.3 \%(\mathrm{w} / \mathrm{v})$.

The final $\mathrm{pH}$ of each medium was $7 \cdot 0$. Media were dispensed in $50 \mathrm{ml}$. portions into $500 \mathrm{ml}$. conical flasks, and autoclaved at $15 \mathrm{lb}$./sq.in. for $5 \mathrm{~min}$.

Table 1. Basal medium for Penicillium cyaneo-fulvum

$\begin{array}{lclr} & \mu \mathrm{g} \cdot / \mathrm{l} . & & \mathrm{g} . / 1 . \\ \text { Nicotinamide } & 1000 & \text { Glucose } & \mathbf{1 0 \cdot 0} \\ \text { Pyridoxine hydrochloride } & 1000 & \mathrm{NaCl} & \mathbf{2 \cdot 5} \\ \text { Calcium-D-pantothenate } & 1000 & \mathrm{KCl} & \mathbf{0} \cdot 2 \\ p \text {-Aminobenzoic acid } & 1000 & \mathrm{CaCl}_{2} & \mathbf{0} \cdot 1 \\ \text { Thiamine } & 1000 & & \\ \text { Riboflavin } & 400 & & \\ \text { Biotin } & 2 \cdot 2 & & \end{array}$

Production and partial purification of TIS. Cultures $(500 \mathrm{ml}$.$) in 21$. Fernbach flasks were removed after 6-7 days quiescent incubation (when the $\mathrm{pH}$ had reached 8.5-8.7). Combined culture filtrates were adjusted to $\mathrm{pH} 7 \cdot 0$, transferred to a separating funnel and saturated with ammonium sulphate. The solid material which rose to the surface was recovered and redissolved in water. After exhaustive dialysis, the solution was freeze dried.

Purification of staphylococcal $\alpha$-toxin. Staphylococcal $\alpha$-toxin, in the form of culture filtrates of Staphylococcus aureus 24 MA, supplied by Dr J. M. B. Corkhill, was purified as follows (Dr A. W. Jackson, 1957, private communication):

Filtrates were dialysed for $4 \mathrm{hr}$. against cold distilled water, and the $\mathrm{pH}$ adjusted to $4 \cdot 6-4 \cdot 8$. Zinc acetate was added in the proportion of $1 \mathrm{ml}$. of a $1 \%(\mathrm{w} / \mathrm{v})$ solution for each $10 \mathrm{ml}$. of filtrate, and the $\mathrm{pH}$ adjusted to $4 \cdot 3$. One half volume of cold $95 \%(\mathrm{v} / \mathrm{v})$ ethanol was slowly added, the mixture being 
immersed in a dry ice + ethanol bath during the addition. Precipitated toxin was removed by centrifugation and was washed with a mixture of $16.5 \mathrm{ml}$. ethanol and $3.5 \mathrm{ml}$. physiological buffer at $\mathrm{pH} \mathrm{7 \cdot 8} \mathrm{(Jackson} \mathrm{\&} \mathrm{Little,} \mathrm{1957).}$ The precipitate was dissolved in a neutral $2 \%(\mathrm{w} / \mathrm{v})$ ethylene diamine-tetraacetate (EDTA), using $1 \mathrm{ml}$. of solution for each $10 \mathrm{ml}$. of original filtrate. The solution was finally dialysed against cold distilled water for $3 \mathrm{hr}$, , using two or three changes of water. Toxin solution prepared by this procedure had approximately $30 \%$ of the activity of the original filtrates.

Assay of staphylococcal $\alpha$-toxin. Toxin was assayed by determining its haemolytic activity in $0.5 \mathrm{ml}$. of a $1 \%(\mathrm{v} / \mathrm{v})$ suspension of washed rabbit erythrocytes in physiological buffer, $\mathrm{pH} 7 \cdot 8$, after incubation at $37^{\circ}$ for $1 \mathrm{hr}$. The potency of toxin solutions was expressed in Burnet Units, a unit being defined as the smallest quantity of toxin that will produce $50 \%$ haemolysis in $1 \mathrm{ml}$. of a $1 \%(\mathrm{v} / \mathrm{v})$ suspension of erythrocytes, after incubation for $1 \mathrm{hr}$. at $37^{\circ}$ (Roy, 1937). Toxin-inactivating activity was expressed in Burnet Unit equivalents, one TIS unit being defined as the amount of TIS required to inactivate one Burnet Unit of toxin.

Analytical methods. Protease activities were estimated by measuring the amount of tyrosine liberated during digestion of a $2 \%$ solution of sodium caseinate (Husain \& McDonald, 1958). The reaction mixture consisted of $9.0 \mathrm{ml}$. of substrate $(\mathrm{pH} \mathrm{7.8})$, to which was added $1.0 \mathrm{ml}$. of TIS solution (containing $2.0-5.0 \mathrm{mg} . / \mathrm{ml}$.) or $1.0 \mathrm{ml}$. of culture filtrate; control mixtures contained $1.0 \mathrm{ml}$. of water. At zero time and after $4 \mathrm{hr}$. incubation at $37^{\circ}$, $2.0 \mathrm{ml}$. samples of the reaction mixture were removed, mixed with an equal volume of $0.6 \mathrm{M}$-trichloroacetic acid, and filtered. The tyrosine contents of the filtrates were determined by the method of Anson (1938). Protease activity was expressed as the number of $\mu \mathrm{g}$. of tyrosine liberated by $1 \mathrm{mg}$. of TIS or by $1 \mathrm{ml}$. of culture filtrate.

Sugar contents of media and of culture filtrates were determined by the method of Somogyi (1945), and protein contents by the ultraviolet absorption method of Warburg \& Christian (1941), using the formula suggested byKalckar (1947).

\section{RESULTS}

\section{Assay of the toxin-inactivating substance}

The method used by Murray et al. (1957) for determining TIS activity followed conventional serological techniques and involved adding an equal volume of filtrate or TIS solution to each tube of serially diluted crude toxin, and incubating for $1 \mathrm{hr}$. Washed rabbit erythrocytes were added to each of the tubes, which were then incubated at $37^{\circ}$ for a further hour. The TIS activity of the filtrate or solution was calculated from the apparent decrease in toxin concentration. This method, however, was found to give inconsistent, and in some instances, completely erroneous results. Since a single reaction mixture containing excess substrate (toxin) and limiting amounts of TIS was clearly preferable to using a series of mixtures in which the toxin concentration varied continuously, it was decided that the detoxifying reaction could best be 
studied by reacting TIS with excess toxin, and then determining the residual toxin by serial dilution. Preliminary experiments had indicated that mould culture filtrates contained substances which interfered with the assay procedure. The effect of these substances on the haemolysis of rabbit erythrocytes would therefore be decreased substantially by serial dilution of a sample from a single reaction mixture. This is particularly important in view of the findings (Bernheimer, 1947; Jackson \& Little, 1957) that haemolysis can be inhibited by certain sugars and organic acids. On the basis of possible interference by substances in the staphylococcal culture filtrate, it was also deemed advisable to employ purified toxin preparations. Finally, serial dilution of the samples taken from the single reaction mixture served as a convenient means of stopping the toxin + TIS reaction.

\section{Factors affecting the inactivation of toxin by TIS}

Haemolysis of rabbit erythrocytes by staphylococcal $\alpha$-toxin occurred optimally at $\mathrm{pH} 7 \cdot 8$ (Fig. 1). This value was higher than that found by

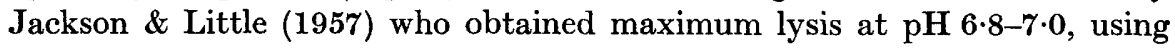
toxin from a different strain of Staphylococcus aureus. The effect of $\mathrm{pH}$ on the inactivation of toxin by TIS is also shown in Fig. 1. Maximum TIS activity was observed in the $\mathrm{pH} 7 \cdot 6-8 \cdot 0$ region, with activity falling off rapidly above $\mathrm{pH} \mathbf{8} \cdot \mathbf{0}$.

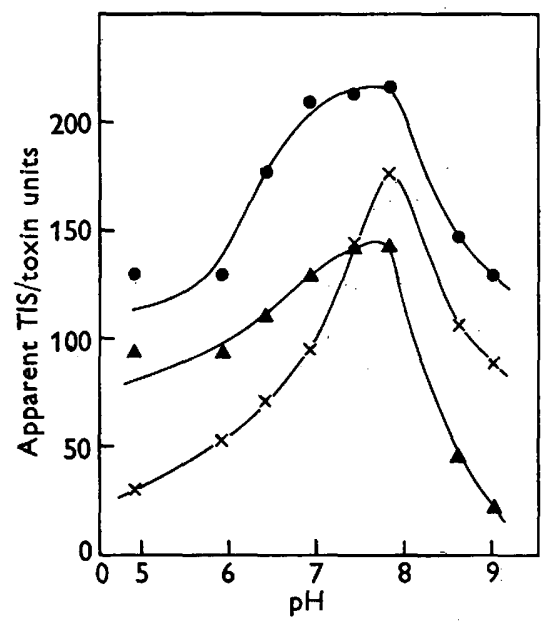

Fig. 1

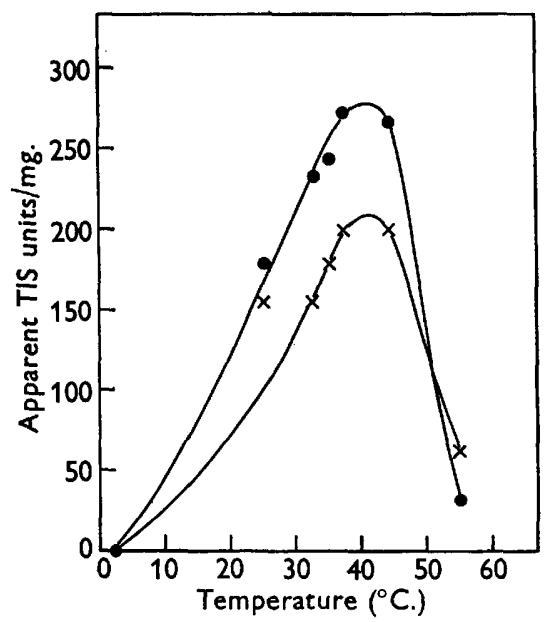

Fig. 2

Fig. 1. Effect of $\mathrm{pH}$ on lysis of rabbit erythrocytes by toxin $(-x-\times-)$, and on the inactivation of toxin by TIS $(0.5 \mathrm{mg} . / \mathrm{ml}$.) after incubation for $1 \mathrm{hr}$. $(-\Delta-\Delta-)$ and $2 \mathrm{hr}$. (-) at $37^{\circ}$. Toxin activity is in units/ml., and TIS activity in units/mg.

Fig. 2. Effect of temperature on the inactivation of toxin by TIS $(0.5 \mathrm{mg} . / \mathrm{ml}$.) after incubation for $1 \mathrm{hr} .(-x-x-)$ and $2 \mathrm{hr}$. (--) at $\mathrm{pH} 7 \cdot 8$. TIS activity is in units $/ \mathrm{mg}$.

Inactivation of toxin by TIS was also dependent upon temperature (Fig. 2), maximum activity being found in the range $36-44^{\circ}$. The apparently complete inhibition of the detoxifying reaction at $2-3^{\circ}$ was of particular interest, in that 
it indicated that the reaction could be stopped by diluting a sample from a reaction mixture with cold buffer, a procedure which proved useful when following the course of the toxin + TIS reaction.

These results (Figs. 1 and 2) suggest that the inactivation of toxin is a relatively slow reaction, since considerable detoxification occurred during the second hour of incubation. The course of the toxin + TIS reaction was therefore examined in more detail. The results (Fig. 3) showed a linear relationship between TIS activity and time during the early part of the reaction, with the rate of reaction decreasing rapidly as detoxification neared completion.

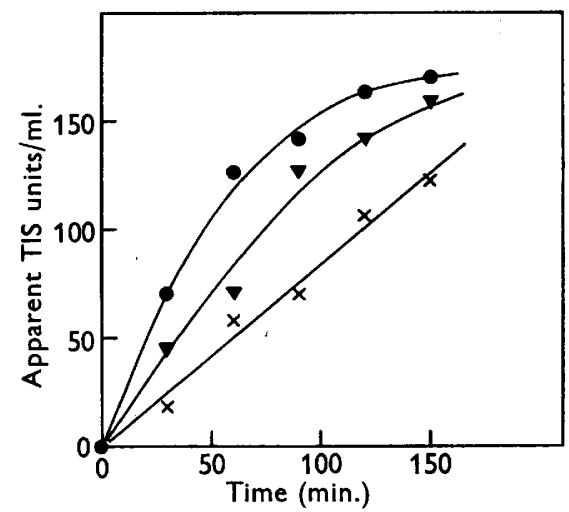

Fig. 3. Effect of incubation time on the inactivation of toxin by TIS at pH $7 \cdot 8$ and $37^{\circ}$. Concentrations of TIS used were $0.2(-x-x-), 0.4\left(-\nabla^{-}-\right)$, and $0.6(---) \mathrm{mg} . / \mathrm{ml}$. TIS activity is in units $/ \mathrm{ml}$.

Assay procedure. A method for assaying TIS activity was based on the observations reported above. To a portion of toxin (usually $0.5 \mathrm{ml}$.), adjusted

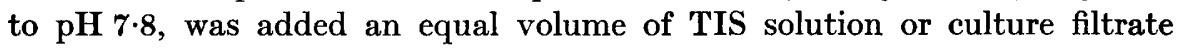
diluted with physiological buffer at $\mathrm{pH} 7 \cdot 8$. The mixture was incubated for $2 \mathrm{hr}$. at $37^{\circ}$, along with control mixtures containing $0.5 \mathrm{ml}$. of water instead of toxin. The toxin contents of the control and of the reaction mixture were then determined as above. It was essential to adjust the TIS content of the reaction mixture such that not more than $75 \%$ of the toxin in the mixture was inactivated, thereby ensuring that the rate of inactivation was linear during the $2 \mathrm{hr}$. incubation period. When assaying culture filtrates, it was necessary to dilute the filtrates with at least an equal volume of buffer, as they contained substances which interfered with the inactivation reaction. An incubation period of $2 \mathrm{hr}$. was considered suitable in that it enabled small amounts of activity to be measured.

\section{Characterization of the toxin-inactivating substance}

The results from the study of factors affecting inactivation of toxin by the mould product suggested a possible enzymic role for TIS. Purified preparations of TIS were therefore examined for enzyme activities that could explain their detoxifying action. This revealed that detoxifying activity in TIS 
preparations and in culture filtrates was always accompanied by marked protease activity. It was essential therefore to establish the relationship between toxin-inactivating and protease activity, and to ascertain the extent to which protease activity contributed to the detoxifying action of TIS preparations and of culture filtrates.

Figure 4 shows the course of TIS excretion by the mould growing in quiescent medium containing beef heart infusion and peptone, in relation to sugar utilization, and to changes in $\mathrm{pH}$ and protease content of the culture filtrate.

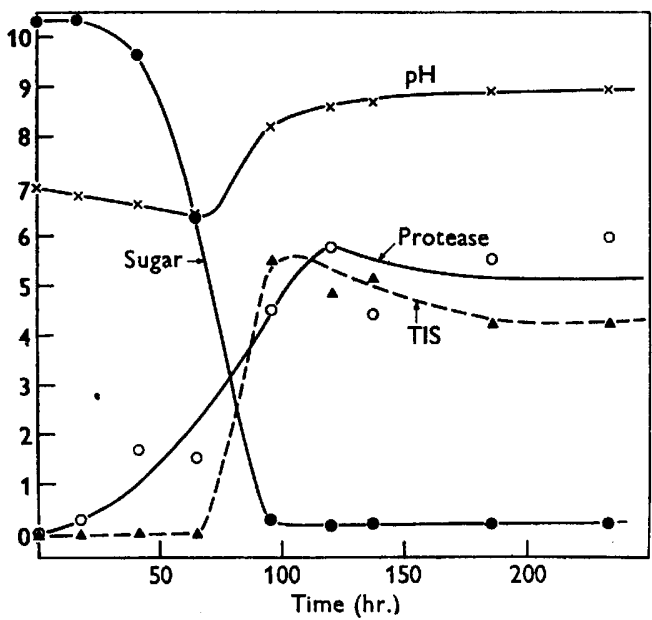

Fig. 4

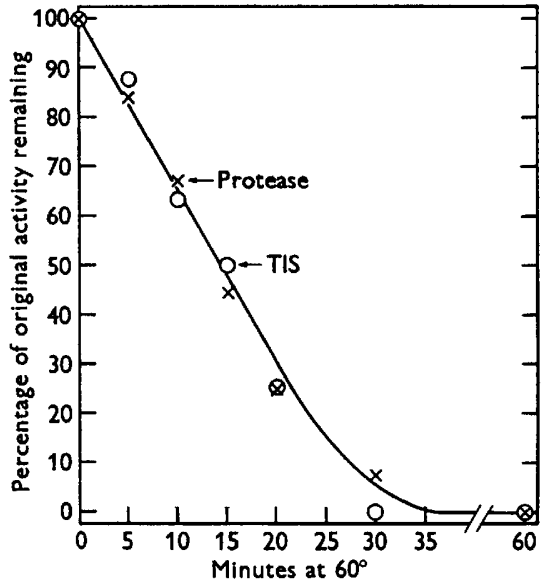

Fig. 5

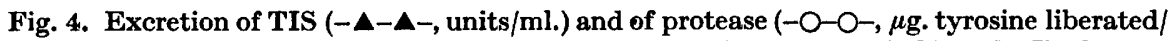
ml.) by the mould, in relation to sugar content $(--, \mathrm{mg} . / \mathrm{ml}$.) and $\mathrm{pH}$ changes $(-x-x-)$ in the culture filtrates.

Fig. 5. Effect of incubation at $60^{\circ}$ on the toxin-inactivating $(-\mathrm{O}-\mathrm{O}-$, units $/ \mathrm{ml}$.) and protease $(-x-x-, \mu \mathrm{g}$. tyrosine liberated $/ \mathrm{ml}$.) activities of a TIS preparation $(2 \cdot 0 \mathrm{mg} . / \mathrm{ml}$.$) .$

Filtrates obtained during the first $60 \mathrm{hr}$. of incubation did not contain detectable amounts of TIS; but as sugar utilization neared completion, TIS was excreted. Protease activity was detectable in culture filtrates before TIS could be demonstrated, although both activities reached a maximum after 100-120 hr. incubation. Further incubation was accompanied by a slight decline in both activities.

When the mould was grown in a medium containing only beef heart infusion as a nitrogen source, the TIS and protease contents of culture filtrates did not reach a maximum until the cultures were 8 days old, corresponding to a delay of $24 \mathrm{hr}$. when compared with excretion in a beef-heart-infusion peptone medium. Filtrates from cultures grown in media containing peptone, casamino acids, or ammonium sulphate as a nitrogen source did not contain detectable amounts of TIS; slight protease activity was occasionally found in these filtrates, but this never attained the values that are associated with detoxifying activity (Table 2). Filtrates from shake cultures of the mould grown in media containing any of these nitrogen sources were also devoid of toxin- 
inactivating ability, although they frequently had slight protease activity (Table 2).

In order to examine further the correlation between toxin-inactivating and protease activities, the active principle (TIS) in filtrates from 6 to 7 -day-old cultures of the mould, grown on a beef-heart-infusion peptone medium, was

Table 2. Toxin-inactivating and protease activities of filtrates from cultures of Penicillium cyaneo-fulvum grown on media containing various nitrogen sources

\begin{tabular}{|c|c|c|c|c|c|}
\hline Nitrogen source & $\begin{array}{c}\text { Quiescent } \\
\text { (Q) or } \\
\text { shaken (S) } \\
\text { culture }\end{array}$ & $\begin{array}{c}\text { Age of } \\
\text { culture } \\
\text { (hr.) }\end{array}$ & $\begin{array}{l}\text { pH of } \\
\text { culture } \\
\text { filtrate }\end{array}$ & $\begin{array}{c}\text { TIS } \\
\text { content of } \\
\text { culture } \\
\text { filtrate } \\
\text { (units/ml.) }\end{array}$ & $\begin{array}{c}\text { Protease } \\
\text { content of } \\
\text { culture } \\
\text { filtrate } \\
\text { ( } \mu \text { g. tyrosine } \\
\text { liberated } / \mathrm{ml} .)\end{array}$ \\
\hline \multirow[t]{2}{*}{$\begin{array}{l}\text { Beef heart infusion }(5 \%) \\
+ \text { peptone }(1 \%)\end{array}$} & $\mathbf{Q}$ & $\begin{array}{r}96 \\
186\end{array}$ & $\begin{array}{l}8 \cdot 2 \\
8 \cdot 9\end{array}$ & $\begin{array}{l}551 \\
438\end{array}$ & $\begin{array}{l}451 \\
552\end{array}$ \\
\hline & $\mathbf{S}$ & $\begin{array}{r}96 \\
186\end{array}$ & $\begin{array}{l}8 \cdot 6 \\
9 \cdot 0\end{array}$ & $\begin{array}{l}\mathbf{0} \\
\mathbf{0}\end{array}$ & $\begin{array}{l}107 \\
152\end{array}$ \\
\hline \multirow[t]{2}{*}{ Beef heart infusion ( $5 \%$ ) } & $\mathbf{Q}$ & $\begin{array}{r}95 \\
161\end{array}$ & $\begin{array}{l}5 \cdot 6 \\
8 \cdot 8\end{array}$ & $\begin{array}{r}71 \\
355\end{array}$ & $\begin{array}{l}313 \\
490\end{array}$ \\
\hline & $\mathbf{S}$ & $\begin{array}{r}95 \\
161\end{array}$ & $\begin{array}{l}4 \cdot 9 \\
8 \cdot 9\end{array}$ & $\begin{array}{l}\mathbf{0} \\
\mathbf{0}\end{array}$ & $\begin{array}{l}0 \\
\mathbf{2} \cdot 0\end{array}$ \\
\hline \multirow[t]{2}{*}{ Peptone (1\%) } & $\mathbf{Q}$ & $\begin{array}{r}65 \\
161\end{array}$ & $\begin{array}{l}4 \cdot 7 \\
8 \cdot 7\end{array}$ & $\begin{array}{l}\mathbf{0} \\
\mathbf{0}\end{array}$ & $\begin{array}{l}19 \cdot 8 \\
49 \cdot 5\end{array}$ \\
\hline & $\mathbf{S}$ & $\begin{array}{r}65 \\
161\end{array}$ & $\begin{array}{l}3 \cdot 9 \\
8 \cdot 7\end{array}$ & $\begin{array}{l}0 \\
0\end{array}$ & $\begin{array}{l}\mathbf{0} \\
0\end{array}$ \\
\hline \multirow[t]{2}{*}{$\begin{array}{l}\text { Casein acid hydrolysate } \\
(1 \%)\end{array}$} & $\mathbf{Q}$ & $\begin{array}{r}91 \\
163\end{array}$ & $\begin{array}{l}4.8 \\
4.5\end{array}$ & $\begin{array}{l}0 \\
0\end{array}$ & $\begin{array}{l}\text { 0 } \\
\text { o }\end{array}$ \\
\hline & $\mathbf{S}$ & $\begin{array}{r}91 \\
163\end{array}$ & $\begin{array}{l}4.7 \\
4 \cdot 6\end{array}$ & $\begin{array}{l}\mathbf{0} \\
\mathbf{0}\end{array}$ & $\begin{array}{l}\mathbf{0} \\
\mathbf{0}\end{array}$ \\
\hline $\begin{array}{l}\text { Ammonium sulphate } \\
(0.3 \%)\end{array}$ & $\begin{array}{l}\mathbf{Q} \\
\mathbf{S}\end{array}$ & $\begin{array}{r}96 \\
186 \\
96 \\
186\end{array}$ & $\begin{array}{l}2 \cdot 5 \\
2 \cdot 5 \\
2 \cdot 5 \\
2 \cdot 4\end{array}$ & $\begin{array}{l}\mathbf{0} \\
\mathbf{0} \\
\mathbf{0} \\
\mathbf{0}\end{array}$ & $\begin{array}{l}\mathbf{0} \\
\mathbf{0} \\
0 \\
0\end{array}$ \\
\hline
\end{tabular}

purified by copper sulphate precipitation (Diena, 1957), and ammonium sulphate fractionation. The following purification procedure was used: copper sulphate was added to the culture filtrate $(350 \mathrm{ml}$.) to a concentration of $1 \%$ $(\mathrm{w} / \mathrm{v})$, and the resulting precipitate removed by centrifugation and discarded. The precipitate obtained on adjusting the $\mathrm{pH}$ of the supernatant to $7 \cdot 8$ was also discarded. Saturation of the remaining solution with ammonium sulphate gave a precipitate which was dissolved in EDTA solution (M/1000) and reprecipitated at full saturation. This second precipitate (fraction I) was dissolved in EDTA solution, and the $\mathrm{pH}$ adjusted to $7 \cdot 8$. The precipitates obtained by adding ammonium sulphate to this solution to $40 \%$ (fraction II) and $60 \%$ (fraction III) saturation were then separated. Further fractions were obtained from an EDTA solution of fraction III by adding two volumes (fraction IV) and four volumes (fraction V) of saturated ammonium sulphate. Saturation of the remaining supernatant with ammonium sulphate gave the final fraction (fraction VI). All fractions were dissolved in $\mathrm{M} / 1000$ versene 
solution, fraction I in $60 \mathrm{ml}$. (10 ml. retained for assay), fraction II in $10 \mathrm{ml}$., fraction III in $25 \mathrm{ml}$. (5 ml. retained for assay), and fractions IV, V and VI in $5 \mathrm{ml}$. Solutions were dialysed against distilled water, and adjusted to $\mathrm{pH} \mathbf{7 \cdot 8}$.

As shown in Table 3, this procedure for purifying TIS led to a seven-fold increase in specific activity (related to protein content). With each fraction, any increase or decrease in TIS activity was always accompanied by a corresponding change in protease activity.

Table 3. TIS and protease activities of fractions from copper sulphate precipitation and ammonium sulphate fractionation of a mould culture filtrate

\begin{tabular}{|c|c|c|c|}
\hline Fraction & $\begin{array}{c}\text { Protein } \\
\text { content } \\
(\mathrm{mg} / \mathrm{ml} .)\end{array}$ & $\begin{array}{c}\text { TIS } \\
\text { activity } \\
\text { (units/mg. } \\
\text { protein) }\end{array}$ & $\begin{array}{c}\text { Protease } \\
\text { activity } \\
\text { ( } \mu \text { g. tyrosine } \\
\text { liberated/mg. } \\
\text { protein) }\end{array}$ \\
\hline $\begin{array}{l}\text { Original cul- } \\
\text { ture filtrate }\end{array}$ & 0.78 & 346 & 599 \\
\hline I & $1 \cdot 30$ & 554 & 775 \\
\hline II & $0 \cdot 83$ & 0 & 69 \\
\hline III & $1 \cdot 75$ & 1223 & 1438 \\
\hline IV & $1 \cdot 80$ & 2461 & 2876 \\
\hline V & $4 \cdot 35$ & 494 & 111 \\
\hline VI & $0 \cdot 63$ & $\mathbf{0}$ & 0 \\
\hline
\end{tabular}

Table 4. Effect of diisopropylfuorophosphate (DFP) on the toxin-inactivating and protease activities of a mould culture filtrate

DFP, diluted in isopropanol, was added to $5 \cdot 0 \mathrm{ml}$. portions of the culture filtrate $(\mathrm{pH} 7 \cdot 0)$, and the total volume diluted to $6.0 \mathrm{ml}$. with phosphate buffer (pH 7.0). Samples were removed after 10 and $20 \mathrm{~min}$. incubation at $37^{\circ}$, and immediately assayed for TIS and protease.

\begin{tabular}{|c|c|c|c|c|c|}
\hline \multirow[b]{2}{*}{$\begin{array}{c}\text { DFP } \\
\text { concentration } \\
(\mathrm{M})\end{array}$} & \multirow[b]{2}{*}{$\begin{array}{c}\text { Period of } \\
\text { incubation } \\
\text { with DFP } \\
\text { (min.) }\end{array}$} & \multicolumn{2}{|c|}{ TIS activity } & \multicolumn{2}{|c|}{ Protease activity } \\
\hline & & Units/ml. & $\begin{array}{c}\% \\
\text { activity } \\
\text { remaining }\end{array}$ & $\begin{array}{l}\mu \mathrm{g} . \text { tyrosine } \\
\text { liberated } / \mathrm{ml} \text {. } \\
\text { filtrate }\end{array}$ & $\begin{array}{c}\% \\
\text { activity } \\
\text { remaining }\end{array}$ \\
\hline $\mathbf{0}$ & - & 142 & 100 & 216 & 100 \\
\hline $10^{-3}$ & $\begin{array}{l}10 \\
20\end{array}$ & $\begin{array}{l}\mathbf{0} \\
\mathbf{0}\end{array}$ & $\begin{array}{l}\mathbf{0} \\
\mathbf{0}\end{array}$ & $\begin{array}{l}1.4 \\
1.0\end{array}$ & $\begin{array}{l}\mathbf{1} \cdot \mathbf{2} \\
\mathbf{0} \cdot \mathbf{9}\end{array}$ \\
\hline $10^{-4}$ & $\begin{array}{l}10 \\
20\end{array}$ & $\begin{array}{r}71 \\
0\end{array}$ & $\begin{array}{r}50 \\
0\end{array}$ & $\begin{array}{l}90 \cdot 8 \\
24\end{array}$ & $\begin{array}{l}42 \\
11\end{array}$ \\
\hline $10^{-5}$ & $\begin{array}{l}10 \\
20\end{array}$ & $\begin{array}{l}142 \\
107\end{array}$ & $\begin{array}{r}100 \\
75\end{array}$ & $\begin{array}{l}202 \\
167\end{array}$ & $\begin{array}{l}93 \cdot 5 \\
77 \cdot 4\end{array}$ \\
\hline
\end{tabular}

Incubation of TIS solutions $(2.0 \mathrm{mg} / \mathrm{ml}$.) in phosphate buffer $(\mathrm{pH} 7 \cdot 8)$ at $60^{\circ}$ for $60 \mathrm{~min}$. led to the complete destruction of both toxin-inactivating and protease activities (Fig. 5). Shorter heat treatments brought about a quantitatively similar destruction of both activities (Fig. 5).

Treatment of proteolytic enzymes with various alkoxyphosphates, including diisopropylfluorophosphate (DFP) is also known to bring about an inhibition of enzyme activity (Balls \& Jansen, 1952). When TIS solutions $(2 \cdot 0 \mathrm{mg} . / \mathrm{ml}$.) in phosphate buffer ( $\mathrm{pH} \mathrm{7.0)}$ ) were treated with DFP at concentrations of 
$10^{-3} \mathrm{M}$ or higher, there was a complete inhibition of detoxifying activity, and a near complete inhibition of protease activity. A small percentage of protease activity always remains after DFP inactivation (Balls \& Jansen, 1952). Lower concentrations of DFP $\left(10^{-4} \mathrm{M}\right.$ and $\left.10^{-5} \mathrm{M}\right)$ caused a partial, but nevertheless quantitatively similar inhibition of both activities (Table 4).

\section{DISCUSSION}

The findings presented in this paper substantially confirm the work of Murray et al. (1957), who demonstrated that culture filtrates of Penicillium cyaneofulvum, grown in a glucose-beef-heart-infusion peptone medium, contained a non-dialysable substance, capable of destroying the haemolytic activity of staphylococcal $\alpha$-toxin. However, the observation that the detoxifying action was extremely rapid could not be substantiated. On the contrary, it was shown that, under the experimental conditions employed, the reaction was still proceeding after $2 \mathrm{hr}$. incubation. The modified assay for TIS gave consistent and reproducible results and, from both the theoretical and experimental aspects, appeared to be preferable to the method used by Murray et al. (1957).

Although the effects of $\mathrm{pH}$, temperature and incubation time on the toxinTIS reaction were examined primarily with the object of establishing the basis of an assay method, the curves showing the effects of $\mathrm{pH}$ and temperature suggest a catalytic role for the action of TIS on toxin. Moreover, the marked correlation between detoxifying and protease activities in all of the preparations studied, both during growth of the mould under various conditions and during purification of TIS, was extremely suggestive of a fundamental relationship between these two activities. The inability to demonstrate detoxifying activity in filtrates possessing low protease activity can probably be explained by a lack of sensitivity inherent in the TIS assay.

The possibility that both detoxifying and protease activities were manifested by the same agent became even more apparent from the closely similar effects of heat, and particularly of DFP on TIS preparations. Inactivation of proteolytic enzymes by DFP is thought to result from the introduction of isopropyl and phosphate groups on the active sites on the enzyme molecule, thereby preventing enzyme turnover (Jansen, Nutting, Jang \& Balls, 1950). The fact that complete inhibition of protease activity in TIS preparations following DFP treatment was accompanied by the disappearance of detoxifying activity suggested that one or more of the active sites implicated in protein breakdown were also essential for toxin inactivation. This was further substantiated by the parallel effects of lower concentrations of DFP on the two activities. Protease inhibition by DFP is confined largely to endopeptidases, the inhibitor being ineffective against carboxypeptidase and many aminopeptidases (Neurath, 1957), which suggests that the enzyme excreted by Penicillium cyaneo-fulvum is an endopeptidase.

Direct evidence of a proteolytic degradation of toxin by detecting tyrosine liberation could not be established, due presumably to the extremely small 
amount of protein in the toxin preparations employed. Nevertheless, the data presented in this paper strongly suggest that the detoxifying activity in culture filtrates of Penicillium cyaneo-fulvum is wholly attributable to proteolytic degradation of the toxin protein. This does not preclude the possibility that several proteases are excreted by the mould, and that only certain of these are involved in toxin inactivation.

Inactivation of bacterial toxins by proteolytic enzymes has been noted by many workers (Walbum, 1929; Brandwijk \& Tasman, 1937; Smythe \& Harris, 1940; Parfentjev, Clapp \& Waldschmidt, 1941). In one of the few detailed studies on this phenomenon, Parfentjev et al. (1941) observed that staphylococcal toxin that had been inactivated with pepsin retained its antigenic properties. The proteolytic activity of the detoxifying substance excreted by Penicillium cyaneo-fulvum could therefore explain the observed toxoiding action of TIS (Tanner, 1958).

Our sincere thanks are due to Miss Aileen Mason, of the Laboratory of Hygiene, Department of National Health and Welfare, Ottawa, Canada, for kindly supplying samples of rabbit blood, to Dr J. M. B. Corkhill, of the Connaught Medical Research Laboratories, University of Toronto, Canada, for providing staphylococcal culture filtrates and to Mr G. A. Grant, of the Defence Research Board, National Defence Department, Ottawa, Canada, for a gift of DFP. The technical assistance of Mr G. D. Powers is also gratefully acknowledged.

This paper is N.R.C. No. 5119.

\section{REFERENCES}

Anson, M. L. (1938). The estimation of pepsin, trypsin, papain and cathepsin with hemoglobin. J. gen. Physiol. 22, 78.

Balls, A. K. \& JANSEN, E. F. (1952). Stoichiometric inhibition of chymotrypsin. Advanc. Enzymol. 13, 321.

Bernhermer, A. W. (1947). Comparative kinetics of haemolysis induced by bacterial and other haemolysins. J. gen. Physiol. 30, 337.

BrandwiJk, A. C. \& Tasman, A. (1937). Action of trypsin on diphtheria toxin. Lancet, 1228.

Cavalli, L. L. (1947). Sostanze ad azione antidotica prodotte da miceti. Boll. Ist. sieroter. Milano, 26, 149.

del Vecchio, G., Del Vecchio, V., Napoli, A. \& Argenziano, R. (1948). Richerche sul potere antidotico. V. Azione del complesso antidotico del liquido culturale di $\boldsymbol{P}$. notatum sul potere antigene della tossina difterica. Boll. Soc. ital. Biol. sper. 24, 186.

Diena, B. B. (1956). A toxin-neutralising substance from Penicillium cyaneo-fulvum: Further studies. Ph.D. Thesis, McGill University, Montreal.

Greene, H. C. \& Fred, E. B. (1934). Maintenance of vigorous mould stock cultures. Industr. Engng Chem. (Industr.) 26, 1297.

Husarn, I. \& MCDonald, I. J. (1958). Characteristics of an extracellular proteinase from Micrococcus Freudenreichii. Canad. J. Microbiol. 4, 237.

Jackson, A. W. \& Littre, R. M. (1957). Staphylococcal toxins. 1. Factors affecting the haemolytic activity of alphatoxin. Canad. J. Microbiol. 3, 47.

Jansen, E. F., Nutting, M. D. F., Jang, R. \& Balls, A. K. (1950). Mode of inhibition of chymotrypsin by diisopropyl fluorophosphate. II. Introduction of isopropyl and elimination of fluorine as hydrogen fluoride. J. biol. Chem. 185, 209. 
KALCKAR, H. M. (1947). Differential spectrophotometry of purine compounds by means of specific enzymes. III. Studies on the enzymes of purine metabolism. J. biol. Chem. 167, 461.

Liv, P. (1954). Inhibition of a staphylococcal haemolysin by a soluble substance produced by a non-haemolytic Micrococcus species. J. Bact. 68, 718.

Metchnikoff, E. (1897). Ricerches sur l'influence de l'organism sur les toxines. Ann. Inst. Pasteur, 11, 801.

Murray, E. D. G., Denton, D. G. \& Stevenson, J. W. (1957). Toxin-inactivating substance and preparation. British Patent No. 787, 607. Dec. 11th.

Neurath, H. (1957). Some considerations of the multiple specificity of proteolytic enzymes. Ann. N.Y. Acad. Sci. 68, 11.

Parfentuev, I. A., Clapp, F. L. \& Waldschmidt, A. (1941). Staphylococcal toxoid prepared by peptic digestion. J. Immunol. 40, 189.

Ramon, G. \& Richou, R. (1945). De l'influence de la chaleur sur les propriétés antagonistes des filtrats de $B$. subtilis à l'égard des bacteries pathogènes et des toxines microbiennes. C.R. Acad. Sci., Paris, 221, 213.

Richou, R. \& Gerbeaux, C. (1952). Les complexes antagonistes. Canad. J. comp. Med. 16, 311.

Rose, A. H. \& Martin, S. M. (1958). Production and properties of a toxin-neutralising substance from Penicillium cyaneo-fulvum. Bact. Proc. 32.

Roy, T. E. (1937). The titration of alpha and beta haemolysins in staphylococcal toxin. J. Immunol. 33, 437.

Smolens, J., McAleer, D. S. \& McLaren, C. S. (1947). Antidotal properties of crude Penicillium notatum filtrate. Proc. Soc. exp. Biol., N.Y., 65, 172.

SmYthe, C. V. \& HarRis, T. N. (1940). Some properties of a haemolysin produced by Group A $\beta$-haemolytic streptococci. J. Immunol. 38, 283.

Somogyi, M. (1945). A new reagent for the determination of sugars. J. biol. Chem. $160,61$.

TANNER, C. F. (1958). The influence of a mold product on the antigenicity of staphylococcal toxin: Further studies. Ph.D. Thesis, McGill University, Montreal.

VILLA, A. M. (1950). Richerche su sostanze ad azione antidotica prodotte da miceti (Attivita dell Aspergillus fumigatus). Mycopathologia (Amst.), 5, 1.

Walbum, L. E. (1929). Toxin and antitoxin. In Handbuch der Pathogen Mikroorganismen, 2, 537. Berlin: W. Kolle and A. V. Wasserman.

Warburg, O. \& Christian, W. (1941). Isolierung und Kristallisation des Gärungsferments Enolase. Biochem. Z. 310, 384.

(Received 30 June 1958) 